\title{
EXPLORATION VERBAL SKILLS AND MOTOR SKILLS OF PRIMARY SCHOOL CHILDREN
}

\author{
Ludmila Miklánková ${ }^{1}$, Michaela Pugnerová ${ }^{2}$, Zdeněk Rechtik $^{1}$, Kateřina Nekvindová ${ }^{1}$ \\ ${ }^{1}$ Assoc. Prof., Department of Primary and Pre-primary Education, Faculty of Education, Palacky \\ University in Olomouc, CZECH REPUBLIC, email: ludmila.miklankova@upol.cz \\ ${ }^{2}$ Dr. Department of Psychology and Abnormal Psychology, Faculty of Education, Palacky \\ University in Olomouc, CZECH REPUBLIC, email: michaela.pugnerova@upol.cz \\ ${ }^{3} \mathrm{Mr}$., Department of Primary and Pre-primary Education, Faculty of Education, Palacky University \\ in Olomouc, CZECH REPUBLIC, email: zdenek.rechtik@upol.cz \\ ${ }^{4}$ Ms., Department of Primary and Pre-primary Education, Faculty of Education, Palacky University \\ in Olomouc, CZECH REPUBLIC, email: katerina.nekvindova99@seznam.cz \\ ${ }^{*}$ Corresponding author
}

\begin{abstract}
The quality of a child's motor skills influences the balanced development of the physical, cognitive, emotional and social components, and is an indispensable element of health promotion and disease prevention. Quality motor skills enable participation in various forms of activities in the children's group and thus contributes to the process of socialization. It is the basis for personal growth in the next stages of human life. The aim of the project is to describe and analyze the relationship between the level of fine motor skills of the child and his cognitive abilities with an emphasis on the level of verbal skills. The research was approved by Ethics Committee of Educational Faculty, Palacky University in Olomouc and took place at primary schools in the Czech Republic. The research group consisted of 96 children with an average age of $9.49 \pm 0.8$ years (girls $9.27 \pm 0.72$, boys $9.78 \pm 0.81$ ). The level of motor skills was monitored by MABC-2 test battery. The cognitive ability test (CAT) was used to determine the level of cognitive abilities. Data were analyzed by correlation analysis and gender differences were assessed based on the results of the t-test. Data were obtained within the project IGA_PdF_2021_017. The results suggest a relationship between some aspects in the child's level of motor skills and vocabulary, including the ability to compose sentences. In the area of vocabulary, gender differences were observed in the research group. Further research conducted on larger groups of children could be aimed not only at deepening knowledge in this area, but also at the future aimed use of children's motorics development programs to support executive functions.
\end{abstract}

Keywords: children, primary school, fine motor skills, verbal skills

\section{INTRODUCTION}

Quality motor skills are the basis for personal growth in the next stages of human life. Primary motor skills are the building blocks for more complex motor skills. In addition, they represent a part of the competencies necessary for participation in various forms of activities of the children's team and thus contribute to the process of integration of individuals into the school team (Sgró, Schembri, Nicolosi, Manzo \& Lipoma, 2013; Payne \& Isaacs, 2011). For younger age groups, children with motor problems are usually not accepted by their peers into physical activities and games (Baerg, Cairney, Hay, Rempel, Mahlberg \& Faught, 2011; Moore, 2008). Motor development as an integral part of the child's development complex is also strongly influenced by a number of factors. It is primarily a family, then interactions with peers, other groups of people in society and other cultures (Greenfield \& Cocking, 2014). The relationship between motor skills levels and environmental stimulation is well established. Lioret, Touvier, Lafay, Volatier and Maire (2008) or Floriani and 
Kennedy (2008) confirmed the positive effect of a physically active model in a questionnaire survey of parents. Roemmich, Epstein, Raja and Yin (2007) find a connection between inactive behavior and environmental conditions at home and in the closest surroundings of the child's place of residence. Children with poorer performance caused, either by parental restraint or physical weakness, lose interest in physical activity. Therefore, school physical education, its quality and effectiveness, can have significant benefits in the motor and social field (Payne \& Isaacs, 2011; Schmidt et al., 2017; Battaglia, Alesi, Tabacchi, Palma \& Bellafiore, 2019). In the Czech Republic, it is currently entirely within the competence of the school and also, depending on the economic possibilities of the school's founder, to improve the spatial conditions for various organizational forms of physical education in the movement regime of the school. As part of physical education, it is necessary to introduce children the possibilities of physical activities in other environments, not only at school, but also in the closest surroundings of the school. Even small differences in experience and environment in childhood can later have a significant impact on human behavior in older age categories. Acquired (learned) motor skills enable effective health promotion and thus act as disease prevention (Smith \& Thelen, 2003; Colella \& Moreno, 2011; Bailey, 2006). Today, the connection between the child's motor skills and the level of his executive functions and cognitive competencies, including verbal competencies, is intensively investigated. Some research confirms the link between better language skills and higher success in reading abilities (Diamond \& Lee, 2011; Vukovic, M, Vukovic, I, \& Stojanovik, 2010; de Bruijn et al., 2019; Iverson \& Braddock, 2011). Exploring the importance of the level of motor skills and its positive role in the development, maintenance and support of brain functions, cognition and academic performance has grown significantly over the last decade (Etnier, 2015; Hillman, Erickson \& Hatfield, 2017; Liu-Ambrose \& Best, 2017; Cadoret et al., 2018; Haapala \& kol., 2019; MacDonald, Milne, Orr \& Pope, 2018).

\section{METHODOLOGY}

The following research questions were solved within the research: 1. Do children with higher levels of motorics have higher levels of verbal abilities? 2. Will primary school children have gender differences in the level of verbal and motor skills? Purpose of the Study: The aim of the project is to describe and analyze the relationship between the level of motorics. and childs cognitive abilities with an emphasis on the level of verbal skills. The partial aim is to assess the differences in the level of verbal skills and motor skills in the context of age in monitored children. The development of motor skills, its manifestations and speech takes place in relation to each other. Awkward children or children with delayed motor development usually have more pronunciation deficiencies than children physically and motorly fit. The poor level of motor skills is reflected in the low number of physical activities in the child's daily routine and thus affects the child's physical, mental and social health. In recent years, the level of physical activity of children has been declining, even in the youngest age categories (Goldfield, Harvey, Grattan, \& Adamo, 2012; Holt \& Mikati, 2011; Reilly et al, 2006). At the same time, the number of specific developmental disorders is increasing, including motor problems (Boyle et al., 2011). The impacts of substandard motor skills on a child's success in fulfilling the obligations associated with compulsory school attendance are a current topic nowadays. Data from the Czech Republic can thus supplement published researches in the given area. The research group consisted of 96 children with an average age of $9.49 \pm 0.8$ years (girls $9.27 \pm 0.72$, boys $9.78 \pm 0.81$ ), who attend primary schools in the Czech Republic. To evaluate the second research question, the research group was divided into two age-differentiated groups. Within primary education in the Czech Republic, the curriculum of education is divided according to the age of children into the first and second educational period. From this point of view, we assessed the differences in the level of verbal and motor skills. The group completing the first educational period of primary education consisted of 52 pupils with an average age of $8.85 \pm 0.35$ years (boys $8.87 \pm 0.34$ years, girls $8.84 \pm 0.37$ years). In the group attending the second educational period of primary education, there were 44 pupils with an average age of $10.24 \pm 0.42$ years (boys $10.31 \pm 0.46$ years, girls $10.17 \pm 0.37$ years). None of the children were obese or had any other disability. Children with physical and other neurological disabilities were not tested. The level of motor skills was monitored by MABC-2 test battery (Henderson, Sugden, \& Barnett, 2007; česká verze Psotta, 2014). The test battery is designed to evaluate the level of motor skills, respectively. motor development. When evaluating basic motor functions, it is assumed that their level is reflected in the output performance and the way of performing sensorimotor tasks. The test contains eight items - movement tasks. Each item is intended to assess one of the following components of motor competence: a manual skill component (fine motor skills), a gross motor component and a balance component. Manual dexterity tests are based on pin placement (MD 1), lacing (MD 2) and drawing a path (MD 3) subtests. Tests focused on gross motor skills include subtests of catching with both hands (AC 1) and throwing a small bag on the mat (i.e. throwing at the target) (AC 2). Tests aimed on balance monitor the balance on the balance board (Bal1), walking forward with the heel touching the toe of the other foot (Bal 2) and hops on the mats (Bal 3). These sub-items are evaluated in accordance with the manual for the administration of the test battery. Test performance scores 
and conversion of raw score to standard score (SS) were assessed according to the MABC-2 Examiner's Manual (Henderson et al., 2007). The cognitive ability test (CAT) (Thorndike \& Hagen, 1998, česká verze Vonkomer, \& Jilek, 1998) was used to determine of verbal skills level. The test is intended for children from 7.6 to 15.9 years of age, so it is suitable for use in this research. The test allows the assessment of an individual's individual ability to use and manipulate abstract and symbolic relationships. The overall profile expressing the level of cognitive abilities of the child is composed of verbal, quantitative and non-verbal areas. To meet the objectives of the research, a part monitoring the level of verbal competencies of the child was used. These competencies are evaluated on the basis of the total score achieved in four subtests, which are focused on the quantity of vocabulary, as well as the ability to complete sentences, the ability to classify concepts and levels of verbal analogy. Data were assessed by correlation analysis. Gender differences data were detected by t-test. Results were obtained within the project IGA_PdF_2021_017. The project was approved by the Ethics Committee of the authors' workplace. The so-called Informed consent was submitted to the legal representatives of the children, where they were introduced to the aims and realization of the research investigation and the anonymity of the data was guaranteed. With mentioned signed consent, the child was included in the research. Participation in the research was free of charge. During the research, the children could withdraw from the research at any time, and in case of questions, they were answered in a form appropriate to their age. The relationship between the level of verbal skills and the level of motor skills, even in the context of children's age, was assessed by correlation analysis of the overall CAT score and the total score of the MABC-2. The rough score was used to analyze the effect of the age factor on performance in both the motor test and the verbal skills level. Gender specificity was assessed by t-test.

\section{RESULTS}

In the subtest "manual peg placement skill" (MD1) children achieved better results with the so-called preferred hand, which is quite logical (Table 1). All paired organs, motor, sensory, organs with internal secretion are subject to the rule of lateralization, i.e. the preferential use of one organ from a pair. During ontogenesis, the first signs of the future development of laterality in the tonic-neck reflex are evident. Until the 4th month of age, children use both hands symmetrically in active motor movements. It is not until about 7 months of age that there is a shift to asymmetric - lateralized performance, due to the maturation of nerve pathways. Consequently, the development fluctuates for a long time between symmetry and asymmetry. Gradual, diagnosable stabilization of laterality occurs only after the 4th year of life of the child. If the laterality of the hand is not defined before the age of 6 , the child should be examined in a pedagogical-psychological counseling center (Kocurová, 2002). Girls in this subtest achieved a better standard score $(11.69 \pm 4.98)$ than boys $(10.71 \pm 4.72)$. In the "threading" subtest (MD2), it is necessary to pass the string through the holes in the plate as soon as possible (Table 1). Here, girls again achieved better results than boys (girls $12.05 \pm 3.02$, boys $10.88 \pm 4.34$ ). The worst results in the area of manual skills were shown by children in the subtest "drawing a path" (MD3) (Table 1), where the aim was to draw a line by a predefined path / corridor within a given time limit. The number of errors, i.e. touches of the line indicating the predefined path, was evaluated. Girls were again more successful in standard scores than boys (girls $9.02 \pm 1.88$, boys $8.54 \pm$ 2.87). From the point of view of gender, the differences in manual skills were not found to be statistically significant, which corresponds to the findings of other authors (Livesey, Coleman, \& Piek, 2007; Allen \& Marotz, 2002; Gallehue \& Ozmun, 1997). Another group of subtests of the used test battery monitored the level of balance abilities of children (Table 1). In "one board balance" (BAL1), the girls showed a standard score using $8.36 \pm 2.66$ for the preferred leg and $8.91 \pm 2.21$ for the non-preferred leg. The boys maintained a stable position for a shorter time and the standard score they achieved is therefore slightly lower compared to girls, both standing on the preferred leg $(8.22 \pm 2.47)$ and standing on the non-preferred leg $(8.15 \pm 2.57)$. The differences between boys and girls are not statistically significant. In the subtest "walking heels to toe forwards" (BAL2) it was necessary to walk the line with the touch of the feet, the so-called heel-toe. The number of correctly performed steps is evaluated. In terms of standard scores, girls and boys achieved similar results (girls $9.71 \pm 1.22$, boys $9.27 \pm 2.00$ ). Proper walking technique and proper unwinding of the foot when walking are part of the primary locomotor skills. In addition, the younger school age is a period in which there is a rapid development of neuromuscular coordination and the level of motor skills, including balance, can thus increase rapidly depending on the amount of acquired motor skills. The third subtest monitoring balance abilities is "hopping on mats" (BAL3), in which the number of correctly performed hops on color-coded pads (without stepping out) is evaluated. Girls were again more successful in this skill (13.78 \pm 4.90) than boys (12.32 \pm 4.52$)$. Based on their research, Jahodová (2013) or Valtr (2012) report significant differences in balance abilities in Czech girls and boys. But this was not confirmed in our research group. The gross motor skills were represented in the MABC-2 test battery by the disciplines "catching with 2 hands" (AC1) and "throwing beanbag onto mat" (AC2). The boys logically showed better results in the standard ball catching score $(10.63 \pm 2.24)$, because ball games such as basketball and handball are very 
popular in the Czech Republic. Many children, mostly boys, also spend their free time outside the school, often in sport clubs and teams. The girls achieved a standard score of only $8.98 \pm 2.67$. In the second discipline in the field of gross motor skills, the girls were able to aim at the target more precisely, and as a result they show higher standard score $(8.76 \pm 2.61)$ than boys $(8.35 \pm 52.83)$, the difference in terms of gender is significant $(p=0.002)$.

Table 1 MABC-2 - standard score $(n=96)$

\begin{tabular}{|c|c|c|c|c|c|}
\hline Subtest & MD1-1[sec] & MD1-1_PSS & MD1-0[sec] & MD1-0_PSS & $\begin{array}{l}\text { MD1_PSSave } \\
\text { rage }\end{array}$ \\
\hline & $27.11 \pm 4,78$ & $9.36 \pm 3.32$ & $31.28 \pm 5.87$ & $8.68 \pm 4.02$ & $11.27 \pm 4.93$ \\
\hline \multirow[t]{2}{*}{ Subtest } & $\begin{array}{l}\text { MD2threa } \\
\text { [sec] }\end{array}$ & MD2_PSS & $\begin{array}{l}\text { MD3draw } \\
\text { [errors in } \\
\text { time - } \\
\text { median] }\end{array}$ & MD3_PSS & \\
\hline & $21.23 \pm 5.52$ & $11.55 \pm 3.69$ & 0 & $8.81 \pm 2.37$ & \\
\hline \multirow[t]{2}{*}{ Subtest } & BAL1-1[sec] & BAL1-1_PSS & BAL1-0[sec] & $\begin{array}{l}\text { BAL1- } \\
\text { 0_PSS2 }\end{array}$ & $\begin{array}{l}\text { BAL1_PSSav } \\
\text { erage }\end{array}$ \\
\hline & $23.79 \pm 8.49$ & $8.30 \pm 2.52$ & $17.46 \pm 9.97$ & $8.58 \pm 2.40$ & $10.63 \pm 4.29$ \\
\hline \multirow[t]{2}{*}{ Subtest } & $\begin{array}{l}\text { BAL2_walk } \\
\text { [number of } \\
\text { correct } \\
\text { steps] }\end{array}$ & BAL2_PSS & $\begin{array}{l}\text { BAL3jump } \\
\text { [number of } \\
\text { correct } \\
\text { jumps] }\end{array}$ & BAL3_PSS & \\
\hline & $14.75 \pm 1.00$ & $9.52 \pm 1.62$ & $4.99 \pm 0.1$ & $9.93 \pm 0.71$ & \\
\hline \multirow{2}{*}{ Subtest } & AC1[points] & AC1_PSS & AC2[points] & AC2_PSS & \\
\hline & $6.63 \pm 2.87$ & $9.69 \pm 2.62$ & $5.93 \pm 2.15$ & $8.59 \pm 2.71$ & \\
\hline
\end{tabular}

Legende: MD1-1... manual peg placement skill with a preferred hand [sec]; MD1-0... manual peg placement skill with a non-preferred hand[sec]; MD1-1_PSS...standard score MD1-1; MD1-0_PSS...standard score MD1-0; MD1_PSSaverage...average of standard score MD1; MD2threa... threading [sec]; MD2_PSS...average of standard score MD2; MD3draw... drawing a path [number of errors];MD3_PSS...average of standard score of drawing a path; BAL1-1... one-board Balance on preferred leg [sec]; $B A L 1-0 \ldots$ one-board Balance on non-preferred leg [sec]; BAL1_PSSaverage ... average of standard score BAL1; BAL2_walk ... walking heels to Toe Forwards[points]; BA $\bar{A} L 2$ _PSS ...average standard score BAL2; BAL3jump ...hopping on mats [points]; BAL3_PSS... average standard score BAL3; AC1 ...catching with 2 hands [points]; AC1_PSS ... average standard score AC1; AC2...throwing beanbag onto mat[points];AC2_PSS...average standard score AC2

In the test of cognitive abilities (CAT) when comparing the score achieved in the S1 subtest in boys and girls, we state that girls $(18.62 \pm 3.97)$ have more vocabulary than boys $(17.77 \pm 5.59)(p \leq 0.001)$. The average score of the whole set evaluating the width of the vocabulary was $18.00 \pm 4.78$. In the subtest "ability to complete sentences" (S2), children were the most successful of all four subtests, the standard score reached $20.17 \pm 3.57$ (girls $19.64 \pm 4.10$, boys $20.88 \pm 2.54$ ). At given age, the child is able to distinguish the superiority of concepts, choose and combine criteria, understand inclusion and relationships between specific concepts. There is decentration in thinking, the child is able to distinguish essential from non- 
essential, attention is not tied to one aspect. The difference in the S2 score achieved between girls and boys is significant $(p \leq 0.04)$. In the ability to classify concepts and orient themselves in them (S3), both groups showed almost identical scores in terms of gender ( $16.47 \pm 3.46$ in total, girls $16.47 \pm 2.87$, boys $16.46 \pm$ 4.11). The last subtest (S4) focused on the level of verbal analogy and was the most difficult for children (standard score $14.50 \pm 4.51$ ). Within this subtest, it was necessary to find a match of some properties between identical / unequal terms. Boys (14.56 \pm 4.87$)$ and girls (14.45 \pm 4.22$)$ again achieved very similar results, which corresponds to the specifics of cognitive development of a given age category. At a younger school age, there is a gradual transition from intuitive thinking to the stage of specific thought operations. The child is capable of different transformations in the mind at the same time, he/she understands identity, reversibility, the interconnection of different thought processes into one sequence. The rough age-related CAT score (HSS) in the observed children $(69.14 \pm 12.32)$ corresponds to the range of the 40th - 69th percentile (HSS girls 69.07 percentile, HSS boys 69.18 percentile). If the rough score were $\leq 25$, it would be a warning to risk level that would require a more detailed examination of the child. However, the result of the standard score achieved by the observed set $(103.48 \pm 11.47)$ is classified according to the CAT test manual as the average performance, without the detected significance between genders.

The results suggest a relationship between some aspects of the level of motor skills and children's vocabulary. Girls with higher levels of motor skills also show a better ability to formulate and form sentences. This correlation is low ( $r s=0.21$ ), but significant at the $p \leq 0.05$ level. In the second research question, we analyzed the differences in the observed variables in terms of age of students. The results of the group of younger children attending the first educational period of compulsory schooling from 6 to about 8 years of age significantly differed in the area of gross motor skills from the group of older children only in the subtest "catching with 2 hands" (AC1) $(p \leq 0.05)$. In the group of boys, a significant improvement of the score in the context of older age was also found in the subtest "hopping on mats" $(p \leq 0.03)$. In group of girls, there was an improvement with increasing age in the subtests of the "manual peg placement skill" $(p \leq 0.14)$ and in the "throwing beanbag onto mat" ( $p \leq 0.02$ ). According to research by Psotta, Hendl, Kokštejn, Jahodová, \& Elfmark (2014), Czech girls achieve better balance skills at the age of 7 , while Czech boys reach better balance at the age of 9 . When comparing the results of research with foreign ones, however, they state the need to adjust the standards for the Czech population. The results in the other MABC-2 subtests in the context of children's age were not statistically significant. The higher level in throwing and catching skills in older boys may be due to the already mentioned higher involvement in sports sections focused on sports games or higher attendance of similar school clubs in their free time. Sports games are also preferred by boys in school physical education. Girls, on the other hand, prefer less "action" physical activity and activities requiring a higher level of neuromuscular coordination. Surprisingly, no statistically significant improvement was found in any of the subtests of the CAT test battery monitoring the level of cognitive abilities in the given research group of children due to the increasing age of the observed pupils. Changes in this area can be influenced both by heredity and by the factors of the social environment in which the child grows up. Family education and learning are considered to be the most important (Jucovičová \& Žáčková, 2014; Morvayová, 2010; Valenta et al., 2018). Other factors include the process of socialization or acceptance and merging of different cultures (Uhrinová, 2007).

\section{CONCLUSIONS}

The given research did not unconditionally confirm the assumption that the monitored children with a higher level of motor skills will also have a higher level of verbal skills. This is despite the fact that children with a higher number of acquired motor skills are more active in school physical education and in their free time outside school, even on weekends, they are usually much more involved in collective physical activities with their peers. And they also communicate far more with adults (coaches, instructors) in sports teams, referees and organizers at sports competitions, etc., which develops verbal skills more. The limits of the research can be considered the non-determination of the influence of frequency, volume and intensity of extracurricular activities and their focus (in the sense of "sports / non-sports") and the size of the research group. Further research carried out on larger groups of children, including in an international context, could be focused not only on deepening knowledge in this area, but also on the possibilities of developing verbal skills through the development of motor skills and the development of other executive functions. Early childhood intervention could help reduce the primary differences between children in motor skills, especially in motor development disorders that are thought to lead to further learning disabilities. 


\section{REFERENCE LIST}

Allen, K. E., \& Marotz, L. R. (2002). Přehled vývoje ditěte od prenatálního období do 8 let. Praha: Portál.

Baerg, S., Cairney, J., Hay, J., Rempel, L., Mahlberg, N., \& Faught, B. E. (2011). Evaluating Physical Activity Using Accelerometry in Children at Risk of Developmental Coordination Disorder in the Presence of Attention Deficit Hyperactivity Disorder. Research in Developmental Disabilities: A Multidisciplinary Journal, 32 (4), 1343-1350.

Bailey, R. Physical Education and Sport in Schools: A Review of Benefi ts and Outcomes. J School Health. 2006, 76 (8), 397-401.

Battaglia, G., Alesi, M., Tabacchi, G., Palma, A., \& Bellafiore, M. The Development of Motor and Pre-literacy Skills by a Physical Education Program in Preschool Children: A Non-randomized Pilot Trial. Front. Psychology, 2019, 9, 2694. https://doi: 10.3389/ fpsyg. 2018.02694

Boyle, C.A., Boulet, S., Schieve, L.A., Cohen, R.A., Blumberg, S.J., Yeargin-Allsopp, M., Visser, S., Kogan, M.D. (2011). Trends in the prevalence of developmental disabilities in US children, 1997-2008. Pediatrics, 2011 Jun; 127 (6):1034-1042. https://doi: 10.1542/peds.2010-2989. Epub 2011 May 23. PMID: 21606152.

Cadoret, G., Bigras, N., Duval, S., Lemay, L., Tremblay, T., \& Lemire, J. (2018).The mediating role of cognitive ability on the relationship between motor proficiency and early academic achievement in children. Human Movement Science, 57, 2018, 149-157, ISSN 0167-9457, https://doi: 10.1016/j.humov.2017.12.002

Colella, D. \& Morano, M. (2011). Gross motor development and physical activity in kindergarten age children. International Journal of Pediatric Obesity, 2011, 6 (S2), 33-36, https://doi: 10.3109/17477166.2011.613661

de Bruijn, A. G. M., Kostons, D. D. N. M., van der Fels, I. M. J., Visscher, C., Oosterlaan, J., Hartman, E., \& Bosker, R. J. (2019). Importance of aerobic fitness and fundamental motor skills for academic achievement. Psychology of Sport and Exercise, 43, 200-209. https://doi.org/10.1016/j.psychsport.2019.02.011

Diamond, A, \& Lee, K. (2011). Interventions shown to aid executive function development in children 4 to 12 years old. Science, 2011, 333 (6045):959-64.

Etnier, J. L. (2015). Physical activity in the prevention of Alzheimer's disease. Kinesiology Review, 4 (1). $28-$ 38. doi:10.1123/kr.2014-0075

Greenfield, P. M., \& Cocking, R. R. (2014). Cross-cultural Roots of Minority Child Development New York, Psychology Press. https://doi.org/10.4324/9781315806884

Floriani, V., $\square$ Kennedy, Ch. (2008). Promotion of physical activity in children. Current Opinion in Pediatrics, 20, 90-95.

Gallahue, D., \& Ozmun, J. (1997). Understanding motor development: infants, children, adolescents, adults (4th ed.). Boston: WCB/McGraw-Hill.

Haapala, E. A., Lintu, N., Väistö, J., Tompuri, T., Soininen, S., Viitasalo, A., Eloranta, A-M., Venäläinen, T., Sääkslahti, A., Laitinen, T., \& Lakka, T.A. (2019). Longitudinal associations of fitness, motor competence, and adiposity with cognition. Med Sci Sports Exerc, 2019, 51, 465-471. doi: 10.1249/MSS.0000000000001826.

Henderson, S. E., Sugden, D. A., \& Barnett, A. L. (2007). Movement Assessment Battery for Children-2 second edition (Movement ABC-2). London, UK: The Psychological Corporation.

Hillman, C. H.; Erickson, K. I., \& Hatfield, B. D. (2017). Run for your life! Childhood physical activity effects on brain and cognition. Kinesiology Review, 2017, 6 (1), 12-21. https:// doi:10.1123/kr.2016-0034.

Holt, R. L., \& Mikati, M. A. (2011). Care for Child Development: Basic Science Rationale and Effects of Interventions. Pediatric Neurology, 44, 239-253. https:// doi.org/10. 1016/j.pediatrneurol.2010.11.009

Jahodová, G. (2013). Diagnostika úrovně motoriky dětí ve věku 8 - 13 let pomocí testové baterie MABC - 2. [Dissertation]. Prag, Charles University, 2013.

Goldfield, G. S., Harvey, A., Grattan, K., \& Adamo, K. B. (2012). Physical Activity Promotion in the Preschool 
Years: A Critical Period to Intervene. International Journal of Environmental Research and Public Health, 9, 1326-1342. https://doi.org/ 10. 3390 /ijerph9041326

Iverson, J. M., \& Braddock, B. A. (2011). Gesture and motor skill in relation to language in children with language impairment. J Speech Lang Hear Res. 2011, 54 (1), 72-86.

Jucovičová, D., \& Žáčková, H. Je naše dítě zralé na vstup do školy? Praha: Grada, 2014. ISBN 978-80-2474750-7.

Kocurová, M. (2002). Specifické poruchy učení a chování. Plzeň: Pedagogické centrum Plzeň, 2002. ISBN: 80-7020-102-9.

Lioret, S., Touvier, M., Lafay, L., Volatier, J. L., \& Maire, B. (2008). Dietary and physical activity patterns in French children are related to overweight and socioeconomic status. American Society for Nutrition Journal, 138, 101-107.

Liu-Ambrose, T., \& Best, J. R. (2017). Exercise is medicine for the aging brain. Kinesiology Review, 6 (1), 22-29. https://doi:10.1123/kr.2016-0035.

Livesey, D., Coleman, R., \& Piek, J. (2007). Performance on the Movement Assessment Battery for Children by Australian 3- to 5-year-old children. Child: Care, Health \& Development, 33 (6), 713-719.

MacDonald, K., Milne, N., Orr, R., \& Pope, R.. (2018). Relationships between Motor Proficiency and Academic Performance in Mathematics and Reading in School-Aged Children and Adolescents: A Systematic Review. International Journal of Environmental Research and Public Health. 2018, 15 (8). https://doi 10.3390/ijerph15081603.

Moore, T. G. (2008). Early childhood intervention: Core knowledge and skills. CCCH Working Paper 3 (November 2008). Parkville, Victoria: Centre for Community Child Health.

Morvayová, P. (2008). Děti trvale žijící v prostředí sociálně vyloučené lokality. Determinanty vzdělávání v sociokulturním kontextu. AntropoWebzin [online]. 2008 (1), s. 27-55. [cit. 2020 - 05 - 31]. (Retrieved from www: http://hdl.handle.net/11025/15599).

Payne, G, \& Isaacs, L. (2011). Human motor development: a lifespan approach (8th edition). Boston, MacGraw Hill.

Pssota, R. (2014). MABC-2, Test motoriky pro dèti. Hogrefe - Testcentrum, Praha.

Reilly, J. J., Kelly, L., Montgomery, C., Williamson, A., Fisher, A., McColl, J. H., \& Grant, S. (2006). Physical Activity to Prevent Obesity in Young Children: Cluster Randomized Controlled Trial. British Medical Journal, 333, 1041. https://doi.org/ 10.1136/bmj. 38979.623773.55

Rudd, J. R., Barnett, L.M., Farrow, D., Berry, J., Borkoles, E., \& Polman, R. (2017). The impact of gymnastics on children's physical self-concept and movement skill development in primary schools, Measurement in physical education and exercise science, 21 (2), 92-100. https://doi: 10.1080/1091367X.2016.1273225.

Sgró, F., Schembri, R., Nicolosi, S., Manzo, G. \& Lipoma, A. M. (2013). A mixed-method approach for the assessment of fundamental movement skills in physical education. Procedia - Social and Behavioral Sciences 106 (2013), 102-111. https://doi: 10.1016/j.sbspro.2013.12.013.

Schmidt, M., Egger, F., Benzing, V., Jäger, K., Conzelmann, A., Roebers, C. M., \& Pesce, C. (2017). Disentangling the relationship between children's motor ability, executive function and academic achievement. PLoS ONE, 2017, 12 (8), e0182845. https://doi. org/10.1371/journal.pone.0182845.

Smith, L. B., \& Thelen, E. (2003). Development as a dynamic system. Trends in Cognitive Sciences, 7, 343348. http://dx.doi.org/10.1016/S1364-6613(03)00156-6

Thorndike, R. I., Hagen E., Vonkomer, J., \& Jílek, J. (1998). Test kognitivních schopností-TKS. Brno: Psychodiagnostika.

Uhrinová, M. (2007). Príčiny školských neúspechov žiakov mladšieho školského veku zapríčinené osobnostnými a sociálnymi činitel'mi. Ružomberok: PF KU, 2007. ISBN 978-80-8084-199-7.

Valenta, M., Michalík, J., \& Lečbych, M. (2018). Mentální postižení. Praha: Grada. ISBN 978-80-271-0378-2.

Valtr, L (2012). Hodnocení motoriky českých dětí předškolního věku testovou baterii MABC-2. [Diplomová práce]. Olomouc, Palacký University. 
van der Leij A, van Bergen E, van Zuijen T, de Jong P, Maurits N, \& Maassen B. (2013). Precursors of developmental dyslexia: an overview of the longitudinal Dutch Dyslexia Programme study. Dyslexia, 2013, 19 (4), 191-213.

Vonkomer, J., \& Jílek, J. (1997). Test kognitivních schopností (TKS). Psychodiagnostika s.r.o. Brno.

Vukovic, M., Vukovic, I., \& Stojanovik, V. (2010). Investigation of language and motor skills in Serbian speaking children with specific language impairment and in typically developing children. Res Dev Disabil, 2010, 31 (6), 1633-44. 